\title{
ALA Awards 1973
}

The following is a list of American Library Association awards for 1973 that might be of interest to ACRL members. They are listed according to their classification as awards, citations, scholarships, and grants for special studies or projects. Each member of the Association is invited to nominate candidates for the following:

Beta Phi MU Award. An annual award, consisting of $\$ 500$ and a citation of achievement, presented to a library school faculty member or to an individual for distinguished service to education for librarianship. Only persons nominated by an ALA member are considered. The nominations must be accompanied by a specific statement of the qualifications of the nominee. Supporting evidence or testimonials are welcomed. Donated by Beta Phi Mu, library science honorary. Administered by the Library Education Division.

Deadline for nominations is January 15, 1973. Jury chairman: to be appointed. Send nominations to staff liaison, Delores Vaughan, $50 \mathrm{E}$. Huron St., Chicago, IL 60611.

Clarence Day Award. An annual award, consisting of a citation, $\$ 1,000$, and a contemporary print. It is made to a librarian or to another individual who has, through substantial published work such as a book, essay, or published lectures, promoted a love of reading. Such work is to have been published within the five calendar years preceding the presentation of the award. Donated by the Association of American Publishers. Administered by the ALA Awards Committee.

Deadline for nominations is January 15 , 1973. Send five copies of nominations to the jury chairman, Ms. Virginia G. Young, 10 East Parkway Dr., Columbia, MO 65201. Staff liaison, Judith F. Krug.

Melvil Dewey Award. An engraved medal and a citation presented annually to an individual or a group for recent creative professional achievement of a high order, particularly in those fields in which Melvil Dewey was actively interested, notably, library management, library training, cataloging and classification, and the tools and techniques of librarianship. Donated by the Forest Press, Inc. Administered by the ALA Awards Committee.

Deadline for nominations is January 15 , 1973. Send five copies of nominations to the jury chairman, Alice J. Appell, Long Beach Public Library, Long Beach, CA 90802. Staff liaison, Judith F. Krug. award established by the American Institute of Architects, the American Library Association, and the National Book Committee to encourage excellence in the architectural design and planning of libraries. Awards are made to all types of libraries. Citations are presented to the winning architectural firms and to libraries; a building plaque is also presented to each library winning an Honor Award. ALA participation authorized by Council in 1962 .

The Library Buildings Award Program is held biennially. The next program will be conducted in 1974; entries will be made in the fall of 1973. Application forms will be available from the Library Administration Division, ALA headquarters. Staff liaison, Ruth R. Frame.

Joseph W. Lippincott Award. An award consisting of $\$ 1,000$, an engraved medal, and a citation of achievement, presented annually to a librarian for distinguished service in the profession of librarianship, such service to include outstanding participation in the activities of professional library associations, notable published professional writing, or other significant activity on behalf of the profession and its aims. Donated by Joseph W. Lippincott. Administered by the ALA Awards Committee.

Deadline for nominations is January 15, 1973. Five copies of nominations should be sent to the jury chairman, David Kaser, Cornell University Libraries, Ithaca, NY 14850. Staff liaison, Judith F. Krug.

Eunice Rockwell Oberly Memorial AWARD. A biennial award given in odd-numbered years, consisting of a citation and a cash award from the income of the Oberly Memorial Fund, presented to an American citizen who compiles the best bibliography in the field of agriculture or one of the related sciences in the two-year period preceding the year in which the award is made. The bibliographies are judged on accuracy, scope, usefulness, format, and special features such as explanatory introductions, annotations, and indexes.

Made possible by a fund established by colleagues in memory of Eunice Rockwell Oberly. Administered by the Association of College and Research Libraries, Agriculture and Biological Sciences Section.

Deadline for nominations is March 15, 1973. Send nominations to the jury chairman, Charles Long, New York Botanical Gardens Library, Bronx, NY 19458. Staff liaison, Beverly Lynch. 
ERATURE. An award consisting of $\$ 500$ and a citation, presented to an American librarian to recognize an outstanding contribution to library literature issued during the three years preceding the presentation. The award will be given only when a title merits such recognition. Donated by the Scarecrow Press. Administered by the ALA Awards Committee.

The deadline for nominations is January 15 , 1973. Send nominations to the jury chairman, David O. Lane, Hunter College Library, City University of New York, New York, NY 10021. Staff liaison, Judith F. Krug.

H. W. Wilson Library Periodical Award. An annual award consisting of $\$ 250$ and a certificate, presented to a periodical published by a local, state, or regional library, library group, or library association in the United States or Canada which has made an outstanding contribution to librarianship. (This excludes publications of ALA, CLA, and their divisions.) All issues for the calendar year prior to the presentation of the award will be judged on the basis of sustained excellence in both content and format, with consideration being given to both purpose and budget. The award is presented only in those years when a periodical merits such recognition. Donated by the $\mathrm{H}$. W. Wilson Company. Administered by the ALA Awards Committee.

The deadline for nominations is January 15 , 1973. Nominations in three copies should be sent to the jury chairman, Karl Nyren, R. R. Bowker Company, 1180 Avenue of the Americas, New York, NY 10036. Staff liaison, Judith F. Krug.

Halsey W. Wilson Library Recruitment AWARD. An annual award consisting of $\$ 1,000$, presented to any local, state, or regional library association, any library school, or any other appropriate group concerned with recruitment to the profession. (To be eligible, a state or regional library association must be a chapter of ALA.) The award is presented for the development of a sustained program of recruitment for librarianship and will be based on a total continuing program, not limited to one year's activity. The criteria upon which selection will be based are: definition of goals; appropriateness and value to the library needs of the area in which the program is conducted; number of individuals entering library school or library employment; number and kind of individuals or groups reached; or other demonstrable results. The money comprising the award will be used for the continuation and further development of a recruitment program. There may be direct application or nomination for this award. Donated by the H. W. Wilson Company. Administered by the ALA Awards Committee.

The deadline for nominations is January 15 ,
1973. Send five copies of nominations to the jury chairman, Walt Browne, Pike-Amite Library System, McComb, MS 39648. Staff liaison, Judith F. Krug.

\section{CITATIONS}

AHIL Exceptional Service Award. A citation presented to a member of the Association of Hospital and Institution Libraries in recognition of exceptional service to AHIL or any of its component areas of service, namely, services to patients, the homebound, medical, nursing, and other professional staff in hospitals, and inmates and professional staff in institutions through, but not limited to, organization and professional leadership, effective interpretation of program, pioneered activity, superior teaching and recruiting activity, and significant research and experimental projects. Donated and administered by the Association of Hospital and Institution Libraries.

The deadline for nominations is November 15,1972 . Send nominations to the jury chairman, Adelia Mustain, 3603 29th St., San Diego, CA 92104. Staff liaison, Ira Phillips.

In keeping with Antioch College's experience-based approach to education, all undergraduate students must spend six to eight quarters off-campus exploring the world of work. During recent years Antioch students have held library positions in the Boston Public Library, Dartmouth College Library, Dayton Public Library, New York Public Library, and Antioch's Olive Kettering Library.

Responsibilities have varied, according to the tasks set forth by the individual library and the level of skills on the part of each student, but in all cases librarians have been enthusiastic about employing Antiochians. They have found the students are bright, motivated, and eager to learn. Antioch students work hard, ask penetrating questions, and are a source of fresh ideas and approaches. In short, they are valuable assets.

If you can offer a three-month or six-month learning and earning opportunity to an Antioch student, please contact the College's Extramural Department, which counsels students in their choice of off-campus employment. You can write or telephone Bart Wechsler, Extramural Department, Antioch College, Yellow Springs, $\mathrm{OH} 45387$. Phone 513/767-7331. 


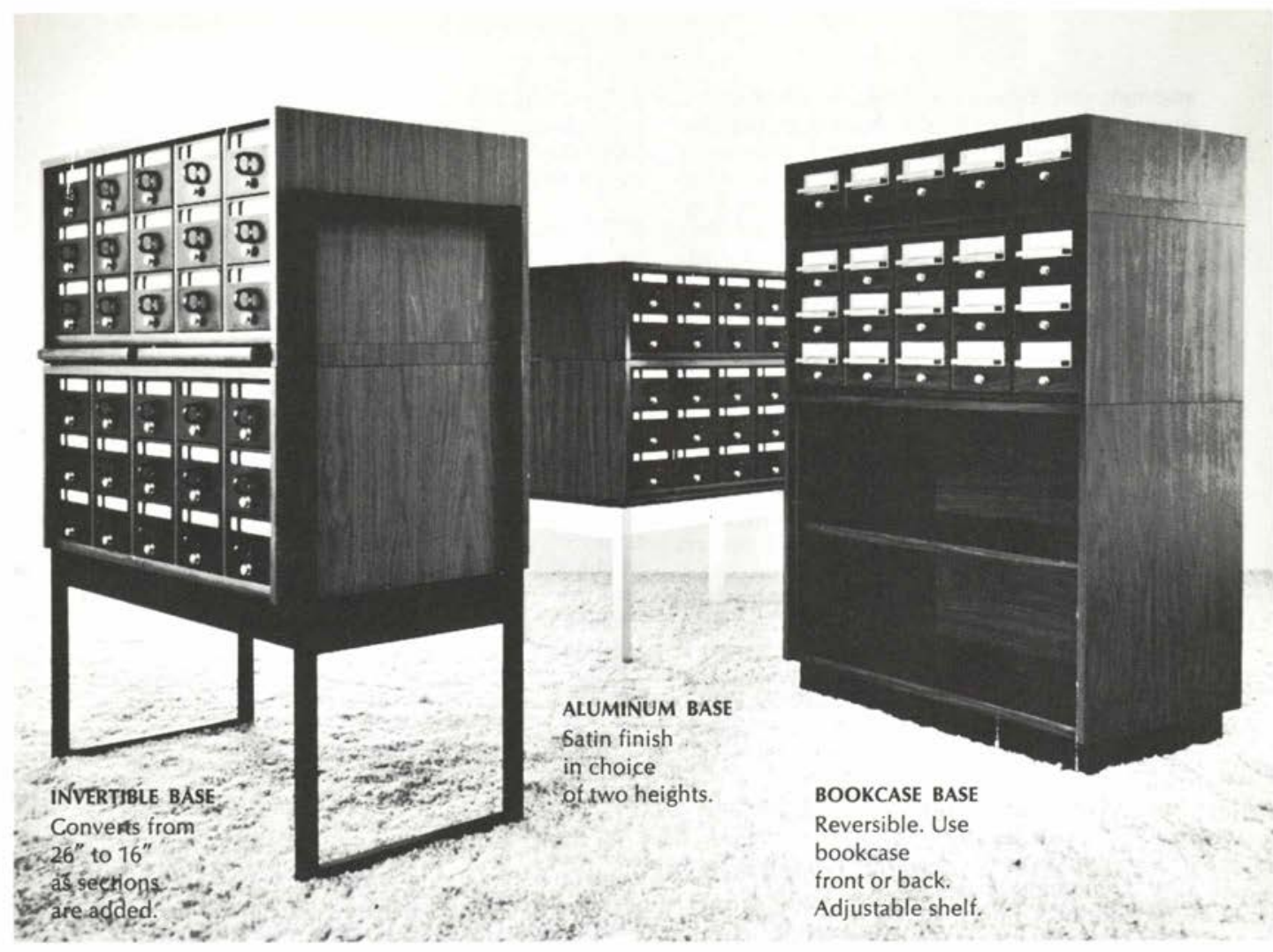

\section{Handsome, Versatile, Practical, Economical}

Modernize your library and increase its efficiency with Gaylord Series 8000 Card Catalog Cabinets. Contemporary "hooded" design ... mar and scratch resistant vinyl laminate surface in warm teak or rich walnut grain finish. High impact plastic trays in 5, 10 or 15 tray sections ... plus your choice of three different base styles.

Combine these attractive sections in any way you like, to get the capacity and flexibility you need. And do it at economical prices, compatible with today's budgets.

Our illustrated brochure sent at your request.

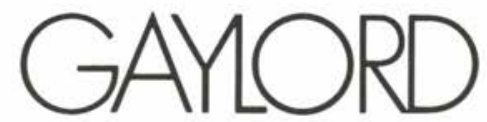

GAYLORD BROS., INC. LIBRARY SUPPLIES AND EQUIPMENT - SYRACUSE, NY 13201 - STOCKTON, CA 95201 
Francis Joseph Campbell Citation. An annual award consisting of a citation and a medal, presented to a person who has made an outstanding contribution to the advancement of library service for the blind. This contribution may take the form of an imaginative and constructive program in a particular library; a recognized contribution to the national library program for blind persons; creative participation in library associations or blind organizations which advance reading for the blind; a significant publication or writing in the field; imaginative contribution to library administration, reference, circulation, selections, acquisitions, or technical services; or any activity of recognized importance. Donated and administered by the Round Table on Library Service to the Blind.

The deadline for nominations is January 15 , 1973. Send nominations to jury chairman, Gisela Titman, Perkins School for the Blind, Watertown, MA 02172. Staff liaison, Ira Phillips.

John Cotton Dana Public Relations Awards Contest. An annual citation made to libraries or library organizations of all types submitting materials representing the year's public relations program. Donated by the H. W. Wilson Company; administered jointly by the Public Relations Section of the Library Administration Division and the Wilson Library Bulletin.

Deadline for entry forms is March 26, 1973. Deadline for scrapbooks is April 9, 1973.

Send entry forms and scrapbooks to John Cotton Dana Public Relations Award Contest, c/o Wilson Library Bulletin, 950 University Avenue, Bronx, NY 10452. Information is available from the jury chairman, Virginia M. Shea, Public Relations Director, Queens Borough Public Library, Jamaica, NY 11432. Staff liaison, Ruth R. Frame.

Margaret Mann Citation. An annual citation made to a cataloger or classifier, not necessarily an American, for outstanding professional achievement in the areas of cataloging or classification, either through publication of significant professional literature, participation in professional cataloging associations, introduction of new techniques of recognized importance, or outstanding work in the area of teaching within the past five years. Donated and administered by the Cataloging and Classification Section, Resources and Technical Services Division.

Deadline for nominations, December 15, 1972. Send nominations with resume of achievement on which nomination is based to jury chairman, William F. Lindgren, Colorado State University Libraries, Fort Collins, CO 80521. Staff liaison, Ms. Carol (Raney) Kelm.
Isadore Gilbert Mudge Citation, A citation to be given at the Annual Conference of the ALA to a person who has made a distinguished contribution to reference librarianship. This contribution may take the form of an imaginative and constructive program in a particular library; the writing of a significant book or articles in the reference field; creative and inspirational teaching of reference service; or other noteworthy activities which stimulate reference librarians to more distinguished performance. Donated and administered by the Reference and Adult Services Division.

Deadline for nominations, March 15, 1973. Send nominations to jury chairman, Florence E. Blakely, Duke University Library, Durham, NC 27706. Staff liaison, Andrew Hansen.

Esther J. Piercy Award. An annual citation presented in recognition of a contribution to librarianship in the field of the technical services by younger members of the profession. The recipient will be a librarian with not more than ten years of professional experience who has shown outstanding promise for continuing contributions and leadership in any of the fields comprising technical services by such means as: (a) leadership in professional associations at local, state, regional, or national levels; (b) contributions to the development, application, or utilization of new or improved methods, techniques, and routines; (c) a significant contribution to professional literature; (d) conduct of studies or research in the technical services. The award will be given each year in which the jury believes there is a qualified recipient. Donated and administered by the Resources and Technical Services Division.

Deadline for nominations, January 1, 1973. Send nominations to jury chairman, Richard R. Centing, Ohio State University Libraries, Columbus, OH 43210. Staff liaison, Ms. Carol (Raney) Kelm.

\section{SCHOLARSHIPS}

ala Scholarship Program. Ala Scholarship Program, approved by the ALA Council, January, 1969 provides scholarships in the amount of $\$ 3,000$ to be given annually to worthy students to begin and/or further their library education at the graduate level without regard to race, creed, color, national origin, or sex. The recipients must enter a formal program of graduate study leading to a degree or advanced certificate at an ALA accredited school. As many scholarships as possible will be awarded, depending upon the total amount of contributed funds. The award may be withheld in any year when there are no worthy recipients. Administered by the ALA Awards Committee and the Library Education Division.

Applications must be submitted by January 
1, 1973. Application and recommendation forms are available from the jury chairman, Charles D. Patterson, School of Library Science, Louisiana State University, Baton Rouge, LA 70803. Staff liaison, Delores Vaughan.

LibRARY BINDING Institute SCHOLARShip. An annual scholarship of $\$ 1,000$ made to a worthy student to further his library education. It is made to a resident of the United States without regard to race, color, creed, or geographical origin. Donated by the Library Binding Institute. Administered by the Library Education Division.

Applications must be submitted by January 10, 1973. Information and application forms are available from the jury chairman, Budd L. Gambee, School of Library Science, University of North Carolina, Chapel Hill, NC 27514. Staff liaison, Delores Vaughan.

John R. Rowe Memorial Award (formerly Exhibits Round Table Award). An annual award of $\$ 500$ made to an individual or group to aid or improve some particular aspect of librarianship or library service on the basis of need in the profession or in the operation of professional library associations. Donated and administered by Exhibits Round Table.

Deadline for applications April 1, 1973. Information and application forms are available from Chris Hoy, Conference Manager, ALA headquarters.

Herbert W. Putnam Honor Fund Award. An award of $\$ 500$ presented at intervals as a grant-in-aid to an American librarian of outstanding ability for travel, writing, or other use that might improve his or her service to the library profession or to society. Administered by the ALA Awards Committee which serves as the jury.

Deadline for applications, March 15, 1973. Nominations should be sent to Robert F. Delzell, Director of Personnel, University of Illinois Library, Urbana, IL 61801. Staff liaison, Judith F. Krug.

\section{News From the Field}

\section{ACQUISITIONS}

- The University of Montreal Libraries is proud to announce that it has received a gift of 3,500 to 4,000 Canadiana books and manuscripts valued at approximately $\$ 500,000$ from Mr. Louis Melzack, a Montreal bookseller and collector. The collection will probably be available to the public sometime in the fall 1972 at the new Melzack Room of the special collections department.

The library also acquired 5,000 original propaganda posters printed by all sides during World War I. In order to put them into usable format, we have had them photographed and put on slides. The Social Sciences and Humanities Library will be able to serve the interested researchers during the fall of 1972 with the slides. The originals are also available, of course.

- A rare collection of letters, photographs, and mementos of the nineteenth century American actor Edwin Booth has been acquired by the library of California State University, Northridge. According to Norman E. Tanis, director of the library, purchase of the collection from the actor's great-granddaughter, Ms. Edwina Booth Cutting, was made possible through the generosity of friends of the library.

Included in the Booth collection is an autographed program dated March 22, 1865, the 100th consecutive performance of Hamlet at New York's Winter Garden Theater. The program, which was issued to commemorate the record-breaking run, includes the text of the play and an essay on Hamlet. Another rare program in the collection is that of an 1886 joint appearance by Booth and the noted Italian actor Tommaso Salvini.

Among the collection's numerous photographs is one showing Booth with another great American actor, Lawrence Berret, which is thought to be the only photograph taken of the two actors together. A rare phonograph recording of Booth reading Othello's speech to the Venetian senate is also included in the collection. The recording was repressed from an original Edison wax cylinder recorded by Booth in limited edition in 1890.

Ms. Cutting stated that a signed letter written in 1879 from Booth to G. H. Howard may be the only extant copy of the actor's original correspondence. Also included in the collection is a charming note in Booth's handwriting to his grandchild. Ms. Cutting also presented the library with personal objects such as a stamp box, a humidor, and a pewter plate which belonged to Booth.

The extensive collection of 253 items contains 128 photographs of Booth and members of his family. The twenty-two books include biographies by Booth's daughter Edwina and sister Asia, and the reminiscences of his lead- 